\author{
Michał Zwierzykowski \\ (Uniwersytet im. Adama Mickiewicza w Poznaniu) \\ Ewa Tacka \\ (Uniwersytet im. Adama Mickiewicza w Poznaniu)
}

\title{
Miejsca obrad sejmików województw Wielkopolski właściwej od XVI do XVIII wieku
}

\author{
The Places of Assemblies of the Local Parliaments of Great Poland \\ from the $16^{\text {th }}$ to the $18^{\text {th }}$ Century
}

\section{STRESZCZENIE}

Artykuł stanowi pierwszą w historiografii próbę syntetycznego ujęcia zagadnienia lokalizacji obrad zgromadzeń sejmikowych tzw. Wielkopolski właściwej w epoce wczesnonowożytnej, z uwzględnieniem jej genezy i przemian. Powstał w oparciu o dotychczasowe, nieliczne i rozproszone ustalenia zawarte $\mathrm{w}$ literaturze, a przede wszystkim na podstawie analizy obszernego, wydanego już drukiem, materiału źródłowego dotyczącego sejmików województw poznańskiego i kaliskiego. Autorzy starali się ukazać nie tylko podstawy zwyczajowe i prawne lokalizacji obrad, miejsca, w których na przestrzeni trzech stuleci obradowała szlachta wielkopolska, ale również przedstawić nieco szczegółów związanych ze zwyczajowym miejscem odbywania sejmików w Środzie. Podstawowy wniosek płynący z ustaleń zawartych w niniejszym tekście potwierdza fakt, że już od drugiej połowy XV w. właśnie Środa była niemal nieprzerwanie centrum politycznych obrad szlachty z rozległego terytorium obejmującego dwa, a od 1768 r. trzy województwa. Poza tym udowodniono, że sejmik wielkopolski w epoce nowożytnej nie miał stałej siedziby, a jedynie potwierdzone zwyczajem i prawem pisanym miejsce gromadzenia się.

Słowa kluczowe: sejmiki, parlamentaryzm, samorząd terytorialny, Rzeczpospolita szlachecka, historia Wielkopolski

Rozważania o lokalizacji obrad sejmików staropolskich należy poprzedzić przypomnieniem, że w przypadku samorządu sejmikowego w dobie przedrozbiorowej nie można jeszcze mówić o „siedzibie” sejmi- 
ku, a jedynie o miejscu obrad ${ }^{1}$. Choć sejmiki miały stałe, tradycyjne miejsca, w których gromadziły się przez stulecia, to jednak korzystały z nich jedynie doraźnie. Po zakończeniu obrad senatorowie i szlachta rozjeżdżali się, nie pozostawiając żadnego urzędu ani funkcjonariusza, który gwarantowałby ciągłość koła sejmikowego. Sejmiki nie posiadały również na miejscu własnego archiwum ani, poza pewnymi wyjątkami, odrębnego wyposażenia ${ }^{2}$.

Zajmując się aspektami prawnymi lokalizacji obrad sejmikowych, należy również pamiętać, że znaczna część sejmikowej praktyki opierała się na prawie zwyczajowym, kształtowanym przez wieki i tylko w niewielkim zakresie kodyfikowanym w formie pisanej - oprócz konstytucji sejmowych trzeba tu wymienić przede wszystkim oficjalne dokumenty zwołujące obrady, wystawiane zazwyczaj przez króla i inne osoby do tego uprawnione. Jednak i źródła pisane najczęściej odwoływały się do zwyczajowości miejsca obrad danego sejmiku. Dopiero w czasach stanisławowskich sejm zaczął realizować planowe reformy, m.in. szeroko opisując $w$ prawie zasady funkcjonowania sejmików. Zrywano przy tym dość często z wcześniejszymi zwyczajami, choć nie zawsze wysiłki te kończyły się sukcesem.

Od schyłku średniowiecza ustalonym miejscem, tzw. locum solitum, locum consuetum lub „miejscem zwyczajnym” odbywania zgromadzeń sejmiku tzw. Wielkopolski właściwej, obejmującej województwa poznańskie i kaliskie, na mocy prawa zwyczajowego i pisanego było miasteczko Środa (dziś Środa Wielkopolska), położone wówczas w powiecie pyzdrskim województwa kaliskiego. Zwyczajowość ta rodziła się stopniowo w pierwszej połowie XV w. Wówczas zgromadzenia kształtującej się dopiero instytucji sejmiku odbywały się w różnych miejscowościach: Poznaniu, Kaliszu, Kole, Pyzdrach, Poniecu i Krobi oraz wielokrotnie w Środzie. Niedługo po wydaniu w 1454 r. przywileju nieszawskiego, wzmacniającego ustrojową rolę sejmików, Kazimierz Jagiellończyk wskazał Środę jako miejsce odbywania sejmików wielkopolskich, kierując się wcześniejszym zwyczajem. Ustalono to podczas sejmu piotrkowskiego w 1459 r. - wyznaczono wówczas stałe terminy dla wszystkich sejmików

${ }^{1}$ Por. np. S. Płaza, Sejmiki i zjazdy szlacheckie województw poznańskiego i kaliskiego. Ustrój i funkcjonowanie (1572-1632), Kraków 1984, s. 78 - gdzie autor wspominał o siedzibie sejmiku województw poznańskiego i kaliskiego w latach 1572-1632. Sejmiki najczęściej wykorzystywały jedynie na obrady obiekty sakralne, rzadziej inne obiekty świeckie (W. Maisel, Archeologia prawna Polski, Warszawa-Poznań 1982, s. 65-66).

${ }^{2}$ M. Zwierzykowski, Samorzad sejmikowy województw poznańskiego i kaliskiego w latach 1696-1732, Poznań 2010, s. 27 i nn.; za chybione uznać należy przypuszczenie B. Urbańskiej, że w skarbczyku przy plebanii kolegiackiej „przechowywano dokumenty sejmików szlacheckich" (B. Urbańska, Kolegiata w Środzie Wielkopolskiej, Środa 2008, s. 22). 
w Polsce, po jednym w ciągu roku dla każdej ziemi czy województwa. Sejmik w Srodzie miał odbywać się przed śródpościem, to jest na przełomie lutego i marca każdego roku, a sejmik w Kole w maju każdego roku. W praktyce zastosowano te uchwały tylko do sejmików w Kole, natomiast dla sejmików średzkich nie zawsze trzymano się nakazanego terminu ${ }^{3}$. Środę jako miejsce odbywania się sejmików województw poznańskiego i kaliskiego potwierdził również sejm w 1496 r., w konstytucji „De locis conventionum ante expeditionem bellicam praemittendarum" - „Videlicet terrigenis [...] Maioris Poloniae et Wschownesibus in Srzoda [...] ad consultandum" ${ }^{\prime 4}$.

Umieszczenie właśnie tam zgromadzeń sejmikowych pozornie może wydawać się dość zagadkowe. Jeśli spojrzy się na mapę ówczesnej Wielkopolski, znacznie bardziej predestynowany do roli głównego ośrodka sejmikowego był Poznań, który był położony centralnie, w miejscu dogodnej przeprawy przez Wartę. W jego obrębie znajdowały się liczne budynki zdatne do goszczenia sejmikujących, a oprócz spraw politycznych w stolicy województwa można było załatwić sprawy urzędowe (w sądach i urzędzie grodzkim), handlowe, religijne czy kulturalne. Można się jedynie domyślać, że lokalizacji miejsca obrad obydwu województw właśnie w Poznaniu sprzeciwiała się szlachta województwa kaliskiego, którego stolica była położona na peryferiach ${ }^{5}$. Środa, miasteczko królewskie, również położone $\mathrm{w}$ dogodnym, centralnym miejscu na terenie powiatu pyzdrskiego i województwa kaliskiego, jednak bliżej Poznania niż Kalisza, wydawała się bardziej neutralna.

Pomimo w miarę centralnego położenia miasta na drodze na sejmik mogły stanąć różne przeszkody - oprócz zawieruchy wojennej i warunków atmosferycznych, również zły stan przepraw przez rzeki. Wielkopolska była bowiem położona w dorzeczu środkowej i dolnej Warty oraz jej

${ }^{3}$ W. Stronczyński, Sejmiki wielkopolskie w pierwszej połowie XV w., Poznań 1966, s. 75 i nn. [rozprawa doktorska, mps w Bibl. Gł. UAM]. Między 1404 a 1452 r. W. Stronczyński wyliczył łącznie 71 zjazdów sejmikowych lub o charakterze sejmiku.

${ }^{4}$ Volumina constitutionum, t. 1, vol. 1: 1493-1526, Warszawa 1996, s. 77; J. Bardach, B. Leśnodorski, M. Pietrzak, Historia ustroju i prawa polskiego, Warszawa 1994, s. 106; M. Zwierzykowski, Funkcjonowanie samorządu sejmikowego województw poznańskiego i kaliskiego od XVI do XVIII w., w: Sejmiki Wielkopolski. Przeszłość i teraźniejszość, red. A. Kamieński, Szczecin-Jarocin 2008, s. 19-33.

${ }^{5}$ Śladem takiej rywalizacji między województwami poznańskim i kaliskim może być decyzja o alternacie odbywania sesji Komisji Skarbowej Poznańskiej, organu wykonawczego sejmiku, raz w Poznaniu, raz w Kaliszu - podjęto ja, zapewne na skutek postulatów obywateli kaliskich, zazdrosnych o uprzywilejowanie Poznania, podczas sejmiku 23 IX 1763 (AP Poznań, Gr. Kalisz 403, k. 2483). Na temat lokalizacji Komisji Skarbowej Poznańskiej zob. M. Zwierzykowski, Komisja Skarbowa Poznańska. Z dziejów sejmikowej administracji i sądownictwa skarbowego w Wielkopolsce w XVII i XVIII wieku, Poznań 2003, s. 127). 
głównych dopływów - Noteci, Obry i Prosny, które w przypadku ulewnych deszczów lub roztopów mogły stać się nie do przebycia. W kompetencjach i interesie sejmiku było utrzymywanie dobrego stanu przepraw przez rzeki, m.in. aby umożliwić szlachcie wielkopolskiej swobodne dotarcie na obrady sejmikowe. Na przykład w laudum z 11 marca 1715 r., w związku z katastrofalnym stanem przeprawy przez Wartę w Śremie, zapisano: „Mając wzgląd na złe przejeżdżającym przez Śrzem do Śrzody ichm. braci przeprawy, mieszczanie śrzemscy nieodwłocznie naprawić kazali, czopowe i szelężne na lat trzy miastu temu Śrzemowi opuszczamy" $^{\prime \prime}$. Po upływie dziesięcioleci za Środą, jako siedzibą sejmiku, przemawiał już długotrwały zwyczaj, będący fundamentalnym elementem kształtowania norm prawnych w ówczesnej Rzeczypospolitej. W dobie nowożytnej, której dotyczy niniejszy artykuł, Środa nadal pozostawała głównym i uprzywilejowanym miejscem obrad.

Najobszerniejsza uchwała sejmiku, poświęcona sprawie miejsca obrad w Środzie została podjęta podczas sejmiku gospodarskiego 6 listopada 1764 r. W laudum zapisano wówczas:

A że zgromadzeniu z obszernych dwóch województw ziemianom miejsce do obrad sejmikowych z dawna wyznaczone jest nieco przyszczupłe, więc dla wygodniejszego placu położenia z drugiej strony kościoła, za pozwoleniem jednomyślnym miejsce obradom wyznaczamy, które za staraniem miasta Szrody zrównane być powinno. Żeby zaś tym większa sposobność zbierania województw obmyślić się mogła, toż miasto ławy dla każdego powiatu, cokolwiek oddzielone wystawić i o nich przezorną na zawsze mieć będzie baczność, niniejszą jest obowiązane uchwałą. A tego ustanowionego jm. pan plenipotent województw naszych, kilką dniami przed sejmikiem zjeżdżać mający, stróżem być powinien porządku.

Dalej zapisano jeszcze uchwałę o wprowadzeniu specjalnego spisu ziemian, ułatwiającego organizację obrad i głosowań ${ }^{8}$. Sprawa była na tyle ważna, że posłowie obu województw zgłosili ją podczas grudniowego sejmu koronacyjnego $1764 \mathrm{r}$. Skutkiem ich postulatu była konstytucja sejmowa, aprobująca wcześniejsze decyzje sejmikowe, w której m.in. zapisano:

${ }^{6}$ Akta sejmikowe województw poznańskiego i kaliskiego. Lata 1696-1732, wyd. M. Zwierzykowski, Poznań 2008, s. 791.

${ }^{7}$ Podobną próbę lokalizacji sejmikowej instytucji poza dwiema stolicami wojewódzkimi podjął sejmik w 1685 r., wyznaczając miejsce obrad dla swojej nowo powoływanej komisji skarbowej w Śremie. W tym przypadku brak tradycji oraz niewielkie możliwości lokalowe i urzędowe miasteczka sprawiły, że bardzo szybko komisja przeniosła się na stałe do Poznania - zob. szerzej M. Zwierzykowski, Komisja Skarbowa Poznańska, s. 127-128.

${ }^{8}$ Laudum sejmiku gospodarskiego w Środzie w dniu 6 XI 1764 (AP Poznań, Gr. Poznań 1221, k. 158-158v). 
Dla porządnego zaś wotowania też województwa ławki na cmentarzu śrzedzkim zrobić dla każdego powiatu każą, aby nikt z innego miejsca, tylko z swej powiatowej ławki wotował, sub non acceptatione voti, a marszałek tychże sejmików z asesorami super realem annotationem votorum et laudi przysiąłłszy, każdego, i na kogo wotującego imię i przezwisko niech notuje, i ad acta województw razem z laudum poda, praesenti lege cavemus 9 .

Sejmik województw poznańskiego i kaliskiego obejmował w XVIXVIII w. swymi kompetencjami tzw. Wielkopolskę właściwą czyli dwa rozległe województwa wielkopolskie - poznańskie i kaliskie, które od średniowiecza tworzyły wspólny okręg sejmikowy ${ }^{10}$. Na jego terenie znajdowało się dziewięć powiatów i jedna ziemia, które odgrywały pewną rolę przy realizowaniu zadań samorządowych, chociażby jako okręgi poborców skarbowych czy jednostki sądowo-administracyjne ${ }^{11}$. W 1768 r., $\mathrm{w}$ wyniku przeprowadzonej przez sejm reformy, ze środkowej części województwa kaliskiego wydzielono nowe województwo - gnieźnieńskie, złożone z powiatów gnieźnieńskiego i kcyńskiego; co interesujące, powiat nakielski miał wchodzić w skład województwa kaliskiego, nie mając już jednak łączności z pozostałą częścią jego terytorium ${ }^{12}$. Nowe województwo pozostało jednak w obrębie średzkiego okręgu sejmikowego. Dopiero pierwszy rozbiór Polski spowodował jego zmniejszenie - państwo pruskie zagarnęło całe powiaty wałecki i nakielski, niemal cały powiat kcyński oraz północne skrawki powiatów poznańskiego i gnieźnieńskiego ${ }^{13}$.

Przeprowadzenie w 1764 r. reformy Trybunału Koronnego i podzielenie go na nowe kadencje ( $\mathrm{w}$ tym w Wielkopolsce na kadencje piotrkow-

${ }^{9}$ Konstytucja "O obieraniu posłów na sejm i deputatów na Trybunał w województwach poznańskim, kaliskim i ziemi wschowskiej” z 1764 r. (Volumina legum [dalej: VL], t. 7, wyd. J. Ohryzko, Petersburg 1860, s. 155).

${ }^{10}$ S. Płaza, Sejmiki i zjazdy, s. 76-78; praktyka funkcjonowania sejmiku Wielkopolski właściwej potwierdza tezę zgłoszoną przez Adama Lityńskiego w kwestii terytorialnej właściwości poszczególnych sejmików jako instytucji prawnych: A. Lityński, Z problematyki klasyfikacji sejmików ziemskich, „Prace Naukowe Uniwersytetu Śląskiego” 1969, 5, Prace Prawnicze 1, s. 89-105; M. Zwierzykowski, Klasyfikacja sejmików na przykładzie funkcjonowania sejmiku województw poznańskiego i kaliskiego w latach 1696-1732, w: O prawie i jego dziejach księgi dwie, ks. 1, red. Zespół, Białystok-Katowice 2010, s. 589-594.

${ }^{11}$ M. Zwierzykowski, Komisja Skarbowa Poznańska, s. 15-17; idem, Odrębności ustrojowe Wielkopolski w dobie nowożytnej, w: Między barokiem a oświeceniem. Staropolski regionalizm, red. S. Achremczyk, Olsztyn 2008 [druk 2009], s. 54-62.

12 Z. Chodyła, Utworzenie $i$ początki funkcjonowania województwa gnieźnieńskiego (1768-1774-1776), w: Gniezno. Studia i materiaty historyczne, t. 2, red. Z. Boras, Warszawa 1987, s. 5-68. Powiat nakielski miał podlegać jedynie pod kompetencje sądu ziemskiego gnieźnieńskiego, choć w skład nowego województwa nie wchodził.

${ }^{13} \mathrm{~J}$. Topolski, Pruskie uzurpacje graniczne w dobie pierwszego rozbioru Polski, "Zeszyty Naukowe Uniwersytetu im. Adama Mickiewicza" 1968, Historia, z. 8, s. 57-72; Dzieje Wielkopolski, t. 1: Do roku 1793, red. J. Topolski, Poznań 1969, s. 867 i nn. 
ską oraz w ramach corocznej alternaty poznańską i bydgoską) nie miały wpływu na dotychczasowy sposób i termin wyboru deputatów - dla obu województw Wielkopolski właściwej, poznańskiego i kaliskiego, w Środzie ${ }^{14}$, jednak podczas sejmu delegacyjnego w 1768 r. podjęto próbę zmiany odwiecznych zwyczajów obowiązujących na sejmikach województwa poznańskiego i kaliskiego. Wraz z utworzeniem nowego województwa gnieźnieńskiego postanowiono, że generalny sejmik przedsejmowy trzech województw będzie się od tej pory odbywał w Poznaniu, poprzedzony przez obrady 10 sejmików powiatowych - w Poznaniu, Kościanie, Wschowie, Wałczu, Nakle, Kcyni, Gnieźnie, Koninie, Pyzdrach i Kaliszu ${ }^{15}$. Na sejmik generalny mieli zjeżdżać posłowie wybrani na sejmikach powiatowych oraz senatorowie i układać wspólny tekst instrukcji. Było to rozwiązanie przypominające dość mocno praktykę sejmików 10 ziem województwa mazowieckiego, które zjeżdżały się na przedsejmowy generał w Warszawie ${ }^{16}$. Sejm z 1768 r. postanowił również, że w Środzie miały odbywać się nadal jedynie sejmiki dla wybrania deputatów przez województwo poznańskie i kaliskie, ale już w nowym terminie, 15 lipca. W konstytucji dokonującej kolejnej reformy działania Trybunału przez stworzenie nowych kadencji (dla prowincji wielkopolskiej w Piotrkowie i Kaliszu), przy wyznaczeniu nowej liczby wybieranych deputatów zapomniano jednak wspomnieć o nowym województwie gnieźnieńskim, kwestię sejmików deputackich dla tego województwa pominięto również $\mathrm{w}$ konstytucji, na mocy której powstało ${ }^{17}$. Określono ją

\footnotetext{
${ }^{14}$ Konstytucja „Rozdzielenie Trybunałów Koronnych” z 1764 r. (VL, t. 7, s. 30).

${ }^{15}$ Po I rozbiorze przestały działać sejmiki całych powiatów zabranych przez Prusy wałeckiego i nakielskiego. Dla resztki powiatu kcyńskiego, mocą uniwersału królewskiego i Rady Nieustającej, sejmik powiatowy przed generałem w Poznaniu i sejmem 1776 r. odbył się w miejscowości Żerniki 15 VII 1776 r. (Z. Chodyła, Utworzenie i początki, s. 57; laudum spisane w Żernikach - AP Poznań, Gr. Gniezno 212, k. 783; instrukcja - AP Poznań, Gr. Gniezno 212, k. 784-784v, 858).

16 J.A. Gierowski, Sejmik generalny księstwa mazowieckiego na tle ustroju sejmikowego Mazowsza, Wrocław 1948.

${ }^{17}$ Konstytucja „Złączenie Trybunałów” z 1768 r. (VL, t. 7, s. 318): „A że przez złączenie Trybunałów, liczbę obieranych zwyczajem dawnym Deputatów, za rzecz sprawiedliwości mniej użyteczną sądziemy, przeto tęż liczbę zmniejszając, obieranie tychże Sędziów niżej opisanym determinujemy sposobem, to jest: [...] Województwo poznańskie i kaliskie wraz sejmikując w Średzie, jednego z poznańskiego, drugiego z kaliskiego deputatów, obierać będzie [...]”; konstytucja „Wojewoda gnieźnieński” z 1768 r. (VL, t. 7, s. 348). W. Bednaruk, Trybunat Koronny. Szlachecki sąd najwyższy w latach 1578-1794, Lublin 2008, s. 90-91. Reform Trybunałów z lat 1768 i 1776 nie uwzględnił w swym najnowszym podręczniku W. Uruszczak (idem, Historia państwa i prawa polskiego, t. 1: 966-1795, Warszawa 2013, s. 263. W monografii dziejów Trybunału Koronnego pióra W. Bednaruka nie znajdziemy niestety informacji o reformach miejsc odbywania sejmików deputackich w Wielkopolsce właściwej w latach 1768-1776 (W. Bednaruk, op. cit., s. 204-207).
} 
jednak w konstytucji „Przepis sejmikom województw wielkopolskich”: „Co się zaś tycze sejmików deputackich, aby na dawnym miejscu przez zgromadzone trzy województwa w Śrzedzie odprawiane były, mieć chcemy, a obieranie to ma być podług opisu sejmu convocationis 1764, co zaś do liczby deputatów, ta ma być według ordynacyi Trybunału na tym sejmie postanowionej". Zapomniano jednak dodać, że województwo gnieźnieńskie powinno mieć również prawo wyboru jednego deputata (skoro prawo takie miały województwa poznańskie i kaliskie). W tej samej konstytucji decyzję o wspólnym odbywaniu sejmiku gospodarskiego (16 VII, dzień po nowym terminie sejmiku deputackiego) przez trzy województwa lub jego podziale na trzy osobne oddano pod decyzję sejmiku generalnego przedsejmowego $\mathrm{w}$ Poznaniu ${ }^{18}$. Podczas sejmu delegacyjnego 1767-1768 r. uchwalono również konstytucję „Porządek sejmikowania”, która wprowadziła kilka fundamentalnych zmian - głosowanie większością na wszystkich sejmikach, zakaz uchwalania własnych podatków, pozbawienie praw szlachty gołoty oraz określenie cenzusu wieku dla uczestników ${ }^{19}$.

Przedstawione wyżej pewne zamieszanie w kwestii sejmików deputackich i deputata $\mathrm{z}$ województwa gnieźnieńskiego jest jednym z licznych dowodów na niekonsekwencję legislacyjną dawnego sejmu i powodowany przez nią nieporządek $w$ prawie pisanym oraz zwyczajowym. $W$ tym przypadku postulat rozwiązania problemu umieszczano $\mathrm{w}$ instrukcjach na kolejne sejmy - z powiatu gnieźnieńskiego (26 IX 1768), z powiatów gnieźnieńskiego i kcyńskiego (22 III 1773), a wreszcie z generału przedsejmowego trzech województw wielkopolskich w Poznaniu (7 IV 1773) ${ }^{20}$. Rozstrzygnął ją ostatecznie sejm delegacyjny rozbiorowy w latach 17731775, w konstytucji dokonującej trzeciej już w niedługim czasie reformy Trybunału Koronnego, polegającej na powrocie do pierwotnych dwóch kadencji prowincji wielkopolskiej - piotrkowskiej i lubelskiej:

Na ten Trybunał deputatów zawsze na dniu 15 lipca, zaczynając się roku teraźniejszego, sposobem w konstytucyi roku 1768, tak co do porządku elekcyi, jako ziem alternat przepisanym, województwa obierać będa, jako to [...] województwo poznańskie w Poznaniu, kaliskie w Kaliszu, gnieźnieńskie w Gnieźnie po jednemu [...] $]^{21}$.

${ }^{18}$ Konstytucja „Przepis sejmikom województw wielkopolskich” z 1768 r. (VL, t. 7, s. 349-350); W. Filipczak, Życie sejmikowe prowincji wielkopolskiej w latach 1780-1786, Łódź 2012, s. 188. Postanowienie to zapewne nie zapadło w związku z rozpoczynającą się konfederacją barską.

${ }^{19}$ Konstytucja „Porządek sejmikowania” z 1768 r. (VL, t. 7, s. 293-294).

${ }^{20}$ Z. Chodyła, Utworzenie i początki, s. 53-54; AP Poznań, Gr. Gniezno 260, k. 269, Gr. Kcynia 164, k. 298v, Gr. Gniezno 245, k. 47v i 56-56v, Gr. Poznań 1221, k. 294.

${ }^{21}$ Konstytucja „Trybunał koronny” z 1775 r. (VL, t. 8, s. 106). 
Tym samym jednak dokonano po raz pierwszy rozdziału wspólnego sejmiku deputackiego województw Wielkopolski właściwej na trzy osobne - skutkowało to zapewne również rozdziałem związanych z deputackimi sejmików gospodarskich. Dla województwa gnieźnieńskiego Zbigniew Chodyła ustalił, że odbyły się według tej konstytucji w Gnieźnie dwa sejmiki deputackie (15 VII 1774 i 15 VII 1775) oraz jeden gospodarski (16 VII 1774), sejmiki pozostałych województw pewnie obradowały w tych samych terminach w Poznaniu i Kaliszu; kwestia ta wymaga jednak dalszych badań22.

Próba zmiany tradycyjnego miejsca obrad sejmików przedsejmowych przeprowadzona w 1768 r., a w przypadku sejmików deputackich i gospodarskich w 1773 r., okazała się jednak słabsza od siły zwyczaju i po perturbacjach konfederacji barskiej oraz okresu sejmu rozbiorowego sejm 1776 r. uchwalił specjalną konstytucję przywracającą wspólne sejmiki do Środy, likwidującą odrębne sejmiki wojewódzkie i powiatowe.

Gdy poznańskie, kaliskie i gnieźnieńskie województwa, jedno zawsze formując ciało, wspólnie na zjazdach swoich miewały obrady, a dopiero konstytucyją 1768 r. osobne powiatom na poselskie sejmiki naznaczono miejsca, która osobność zamiast co by łatwość naradzenia się przynosić miała, bywa przyczyną nieporozumienia się powiatów. Chcąc zatym do dawnej te obrady wprawić jedności, sejmiki rzeczonych województw podług dawnych praw, tak poselskie, jako i deputackie na dawne miejsce, to jest do miasta Śrzody, w czasie przez ostatnie prawo przepisanym przywracamy, w którym miejscu i czasie, tak deputatów ze wszystkich trzech województw wyżej wspomnionych, tudzież posłów w liczbie konstytucyją 1768 roku wyrażonej, przez województw sobie obywatele aby obierali, mieć chcemy ${ }^{23}$.

Znacznie głębsze zmiany $\mathrm{w}$ wielkopolskim mechanizmie sejmikowym wprowadził Sejm Wielki. W uchwalonym w maju 1791 r. obszernym prawie o sejmikach zajęto się również miejscami obrad sejmików. Poświęcono temu zagadnieniu już pierwszy artykuł, w którym napisano: „Na każdy sejmik jedno miasto, a w mieście jedno miejsce do sejmikowania raz na zawsze naznaczamy". W przypadku zniszczenia miasta, uniemożliwiającego obrady, lokalna komisja porządkowa miała poinfor-

22 Z. Chodyła, Utworzenie i poczatki, s. 54; AP Poznań, Gr. Gniezno 209, k. 564v, 565 $565 v, 567$ v-568, Gr. Gniezno 211, k. 52-52v.

${ }^{23}$ Konstytucja „Powrócenie obrad województw poznańskiego, kaliskiego i gnieźnieńskiego na dawne miejsce do miasta Śrzody" z 1776 r. (VL, t. 8, s. 558); R. Łaszewski, Sejmiki przedsejmowe w Polsce stanisławowskiej. Problemy organizacji i porzadku obrad, „Acta Universitatis Nicolai Copernici" 1977, Prawo XV, s. 106; W. Filipczak, Sejmy Rzeczypospolitej w dobie stanisławowskiej, w: Między konstytucja nihil novi a ustawodawstwem nowoczesnej demokracji. Parlamentaryzm polski w XVI-XX w., red. H. Gmiterek, S. Piątkowski, J. Wrona, Radom 2005, s. 71; idem, Życie sejmikowe, s. 188. 
mować Straż Praw o tym fakcie oraz zalecić miejsce zastępcze. O tymczasowym przeniesieniu decydować miał każdorazowo specjalny uniwersał królewski. Lokalna komisja porządkowa miała również dbać o wygląd i wyposażenie miejsca sejmikowego, dysponując na ten cel dobrowolnie uchwaloną przez lokalną szlachtę składką ${ }^{24}$. Szczegółowy rozkład sejmików na mapie Rzeczypospolitej Sejm Wielki uchwalił 2 listopada $1791 \mathrm{r}$. w odrębnej konstytucji. Dawne terytorium sejmikowe poznańsko-kaliskie podzielono na wiele mniejszych okręgów. Utrzymując podział na trzy województwa, w ich ramach wydzielono nowe granice powiatów, uwzględniając ubytki po I rozbiorze. Powiat poznański - sejmik w Poznaniu w kościele pojezuickim, powiat kościański - w Kościanie w kościele farnym, powiat międzyrzecki (zamiast dawnego wałeckiego) - w Międzyrzeczu w kościele farnym, ziemia wschowska - we Wschowie w kościele farnym, powiat kaliski - w Kaliszu w kościele oo. Kanoników Regularnych, powiat koniński - w Koninie w kościele farnym, powiat pyzdrski - w Pyzdrach w kościele farnym, powiat średzki - w Srodzie w kościele farnym, powiat gnieźnieński - w Gnieźnie w kościele farnym i powiat kcyński - w Wągrowcu w kościele farnym. Podział ten dotyczył jedynie sejmików poselskich i relacyjnych. Sejmiki komisarskie, deputackie, gospodarskie oraz dawne elekcyjne na urzędy wojewódzkie miały się odbywać odrębnie dla trzech województw, w ich stolicach ${ }^{25}$. Decyzje Sejmu Wielkiego miały na zawsze zerwać z wielowiekową tradycją wielkopolskiej wspólnoty sejmikowej. Przeszkodził temu II rozbiór, który w 1793 r. poddał całą Wielkopolskę pod panowanie pruskie.

Analizując miejsca obrad sejmiku województw poznańskiego i kaliskiego, nie sposób nie wspomnieć o odbywanych dość regularnie od $\mathrm{XV}$ w. zgromadzeniach elekcyjnych na urzędy sądowe ziemskie. W wielkopolskiej praktyce ustrojowej zgromadzenia te, choć wzorowane na sejmikowych (m.in. obrady pod przewodnictwem wybieranego marszałka, spisywanie aktu elekcji $w$ formie laudum), nie były jako takie traktowane. Dość konsekwentnie nazywano je po prostu elekcjami. Wpływ na to miał przede wszystkim fakt, że na obszernym terytorium sejmiku województw poznańskiego i kaliskiego funkcjonowały aż trzy okręgi sądowe ziemskie, a w ich obrębie zwoływano trzy odrębne elekcje - dla województwa poznańskiego w kościele farnym w Poznaniu, dla województwa kaliskiego w kościele Kanoników Regularnych w Kaliszu i wreszcie dla

\footnotetext{
${ }^{24}$ Prawo o sejmikach z 28 V 1791 r. (VL, t. 9, Kraków 1889, s. 233).

${ }^{25}$ Konstytucja „Rozkład województw, ziem i powiatów z oznaczeniem miast, a w nich miejsc konstytucyjnych dla sejmików w prowincyjach koronnych i W. Ks.L." z 2 XI 1791 r. (VL, t. 9, s. 334-335).
} 
ziemi wschowskiej we Wschowie, w kościele farnym ${ }^{26}$. Od 1768 r. powołano jeszcze jeden odrębny okręg sądowy ziemski dla nowego województwa gnieźnieńskiego przez podział dotychczasowego okręgu kaliskiego. Elekcje miały odbywać się w Gnieźnie, w tamtejszym kościele farnym ${ }^{27}$.

Stan badań nad dziejami nowożytnymi sejmiku województw poznańskiego i kaliskiego nie pozwala jeszcze na całościową analizę miejsc, w których odbywały się obrady. Możemy jednak ukazać to na kilku przykładach opracowanych już okresów.

Na podstawie wydanego przez Włodzimierza Dworzaczka materiału sejmikowego województw poznańskiego i kaliskiego z lat 1572-1632 można jednoznacznie stwierdzić, że Środa była głównym miejscem obrad, odbyła się tam większość zgromadzeń sejmikowych. Poza nią obradowano wyjątkowo na polach pod miastem lub w innych miejscach w obozach pospolitego ruszenia. Nadzwyczajne zjazdy polityczne odbywały się też m.in. w Poznaniu, Kaliszu czy Pyzdrach ${ }^{28}$. Zupełne osobne zagadnienie stanowią ówczesne sejmiki generalne (tzw. generały) prowincji wielkopolskiej, gromadzące się z reguły w Kole ${ }^{29}$. Podobna praktyka utrzymywała się również za panowania Michała Korybuta i Jana III Sobieskiego, kiedy to na 100 ustalonych zgromadzeń sejmikowych jedynie 6 (zaledwie 6\%) zjazdów i sejmików gromadzących się na pospolitym ruszeniu, popisach lub w sposób nadzwyczajny obradowało poza Środą - pod Kołem ${ }^{30}$, Lublinem $^{31}$ czy na zamku w Poznaniu ${ }^{32}$.

Spośród 206 ustalonych i sklasyfikowanych w latach 1696-1732 zgromadzeń sejmiku aż 178 (86\%) odbyło się w zwyczajowym miejscu, w Środzie. Oprócz nich trzy dalsze odbyły się w pobliżu miasta (w tekstach

${ }^{26}$ M. Zwierzykowski, Sejmik województw poznańskiego i kaliskiego w latach 1696-1702, w: Scripta Minora, t. 4, red. B. Lapis, Poznań 2006, s. 427-428; idem, Samorząd sejmikowy, s. 87.

${ }^{27}$ Odrębne sęstwo ziemskie gnieźnieńskie powołano na mocy konstytucji sejmu 1768 r., organizującej nowe województwo, pt. „Wojewoda gnieźnieński” (VL, t. 7, s. 348); Z. Chodyła, Utworzenie i początki, s. 23.

${ }^{28}$ Akta sejmikowe województw poznańskiego i kaliskiego, t. 1: 1572-1632, wyd. W. Dworzaczek, cz. 1: 1572-1616, Poznań 1957, cz. 2: 1616-1632, Poznań 1961.

${ }^{29}$ Ostatni tego typu zjazd w Wielkopolsce odbył się w Kole 30 X 1702 r. (Akta sejmikowe 1696-1732, s. 298 i nn.). Instytucja generałów zanikała od początku XVII w. na rzecz sesji prowincjonalnych podczas obrad sejmów. Sprawa funkcjonowania sejmików generalnych nadal czeka na swojego badacza.

${ }^{30} 27$ VII 1671 na popisie pod Kołem (Akta sejmikowe województw poznańskiego i kaliskiego. Lata 1668-1695, wyd. M. Zwierzykowski, R. Kołodziej, A. Kamieński, w przygotowaniu do druku).

314 IX 1671, 4 XI, 12 i 13 XII 1672 na pospolitym ruszeniu pod Lublinem (Akta sejmikowe 1668-1695).

32 Zjazd zwołany przez starostę generalnego Wielkopolski na dzień 18 XII 1673 (Akta sejmikowe 1668-1695). 
źródłowych zapisywano wówczas „pod Środą”). W dniu 27 sierpnia obradowano w obozie pod Środa, dokładnie we wsi Nadziejewo, pod namiotami pospolitego ruszenia ${ }^{33}$. Obóz znajdował się tam prawdopodobnie co najmniej do 10 września, kiedy zgodnie z prawem przypadało w Środzie zgromadzenie deputackie sejmiku - 15 września sejmik obradował już pod Stawiszynem ${ }^{34}$. Po kilkuletniej przerwie, 29 lipca i 9 września 1709 r. dwa zgromadzenia również obradowały w polu pod miastem, ale tym razem $\mathrm{z}$ uwagi na groźbę zarazy, jaka ciążyła nad tradycyjnym miejscem zgromadzeń - nie wiemy dokładnie, gdzie zatoczono wówczas koło sejmikowe. Podczas zgromadzenia 7 stycznia 1710 r., jak informuje zapis w laudum, obóz zatoczono pod Środa, pod wsią Źrzenica (dziś Źrenica), jednak drugiego dnia, z powodu zimna, obrady przeniesiono do Miłosławia ${ }^{35}$.

Przez cały okres 36 lat jedynie 25 zgromadzeń (12\%) z różnych przyczyn odbyło się $\mathrm{w}$ oddaleniu od uświęconego prawem i zwyczajami miejsca. Podczas pospolitego ruszenia koło sejmikowe obradowało pod Buszewem $^{36}$, Cieślami ${ }^{37}$, Nakłem ${ }^{38}$, Ostrowcem Świętokrzyskim ${ }^{39}$, Stawiszynem $^{40}$, Nakwaszynem ${ }^{41}$ i Uniejowem ${ }^{42}$, trzykrotnie pod Kołem ${ }^{43}$ i Kościanem ${ }^{44}$. W okresie zamieszania politycznego okresu rokoszu łowickiego w 1698 r. i lat 1703/1704 również w Jarocinie ${ }^{45}$, Kaliszu ${ }^{46}$, dwukrotnie w Kościanie ${ }^{47}$ i Poznaniu ${ }^{48}$, a podczas panującej w Środzie zarazy w 1710 r.

${ }^{33}$ Na ten dzień przypadała limitacja sejmiku z 13 VIII 1703 (Akta sejmikowe 1696-1732, s. 351), a miejsce wyznaczył w swoim uniwersale marszałek sejmiku i konfederacji Piotr Jakub Bronisz (Akta sejmikowe 1696-1732, s. 353).

${ }^{34}$ Ibidem, s. 362 i nn.

${ }^{35}$ Ibidem, s. 553, 555, 559.

3628 VII 1704 (Akta sejmikowe 1696-1732, s. 435).

374 VIII 1704 (Akta sejmikowe 1696-1732, s. 437).

${ }^{38} 17$ VIII 1716 (Akta sejmikowe 1696-1732, s. 839).

${ }^{39} 12$ IX 1702 (Akta sejmikowe 1696-1732, s. 287-292). Wcześniej, ok. połowy sierpnia, koło sejmikowe znajdowało się pod wsią Chełmce koło Kalisza, skąd podążając tropem oddziału szwedzkiego gen. Gyllenstierny skierowało się na południowy wschód (Akta sejmikowe 1696-1732, s. 285-286). Na początku września obóz stacjonował pod Opatowem (woj. sandomierskie) (Akta sejmikowe 1696-1732, s. 289).

${ }^{40} 15$ IX 1703 (Akta sejmikowe 1696-1732, s. 363).

${ }^{41} 26$ IX 1703 (Akta sejmikowe 1696-1732, s. 367).

4214 XI 1703 (Akta sejmikowe 1696-1732, s. 384).

4315 V 1697, 1 V 1698, 29 VI 1716 (Akta sejmikowe 1696-1732, s. 110, 147, 830).

449 VI i 14 VII 1704, 25 V 1716 (Akta sejmikowe 1696-1732, s. 422, 429, 826).

${ }^{45} 17$ III 1698 (Akta sejmikowe 1696-1732, s. 143).

${ }^{46} 15$ X 1703 (Akta sejmikowe 1696-1732, s. 375).

4712 XI 1703 i 2 XII 1704 (Akta sejmikowe 1696-1732, s. 378, 444).

4813 I i 15 II 1698 (Akta sejmikowe 1696-1732, s. 126, 131). 
sześciokrotnie w Miłosławiu ${ }^{49}$. Wśród wymienionych wyżej miejscowości, dwie położone były poza terytorium sejmikowym - Uniejów w województwie łęczyckim oraz Ostrowiec Świętokrzyski w województwie sandomierskim.

Obradując w polu, zapewne rozbijano namioty, co było normalną praktyką podczas pospolitego ruszenia, z uwagi jednak na liczebność zgromadzenia zataczano koło bezpośrednio pod gołym niebem, umożliwiając swobodniejszy udział wszystkim. Kiedy obradowano poza tradycyjnym miejscem, korzystano najczęściej z obiektów sakralnych. W 1698 r., podczas zjazdu styczniowego w Poznaniu, kontyści obradowali w kościele Franciszkanów ${ }^{50}$, w przypadku ich zjazdu lutowego brak niestety informacji. Nie wiemy również, gdzie obradowali 17 marca 1698 r. w Jarocinie, który jako miasteczko prywatne należał do kasztelanica krzywińskiego Andrzeja Radolińskiego, najpewniej popierającego wówczas elekta Contiego ${ }^{51}$. W 1703 r. w Kaliszu obradowano w kościele Kanoników Regularnych $^{52}$, o miejscu dwukrotnych obrad w Kościanie nie mamy bliższych informacji, jednak w tym mieście były do dyspozycji dwa duże kościoły - parafialny pod wezwaniem Wniebowzięcia Najświętszej Maryi Panny, pochodzący z XIV w. oraz kościół Bernardynów - z początków XVII w. . $^{53}$. Najdłużej, bo aż sześciokrotnie, sejmik między 8 stycznia a 28 lipca $1710 \mathrm{r}$. gościł w Miłosławiu, prywatnym miasteczku leżącym w odległości kilkunastu kilometrów od Środy, w której obrady uniemożliwiła panosząca się wówczas zaraza. Niestety, w zachowanym materiale źródłowym nie ma żadnych informacji o miejscu, w którym obradowało koło sejmikowe województw poznańskiego i kaliskiego. W mieście był wówczas do dyspozycji kościół parafialny pod wezwaniem św. Jakuba, wybudowany ok. 1620 r. jako zbór luterański, a już w 1629 r. oddany katolikom. Była to budowla w stylu późnogotyckim, trzynawowa, zapewniająca warunki podobne do tych, jakie sejmikujący mieli w Środzie. O tym, że w Miłosławiu przynajmniej styczniowe obrady koła odbywały się na wolnym powietrzu, świadczyć może zapis w diariuszu sejmikowym, informujący, że przyczyną przenosin sejmiku spod Środy było panujące zimno ${ }^{54}$.

497 I (obrady przeniesione spod Środy), 3 II, 24 III, 26 V, 16 VI i 28 VII 1710 (Akta sejmikowe 1696-1732, s. 574, 580, 585, 591, 594, 599).

${ }^{50}$ Akta sejmikowe 1696-1732, s. 130.

${ }^{51}$ Dzieje Jarocina, red. Cz. Łuczak, Poznań 1998, s. 112.

${ }^{52}$ Akta sejmikowe 1696-1732, s. 377.

${ }^{53}$ Kościan. Zarys dziejów, red. Z. Wielgosz, K. Zimniewicz, Warszawa-Poznań 1985, s. 37 i nn. Autorzy nie wspomnieli jednak o przypadkach obrad sejmikowych w Kościanie.

54 "Tandem dla niepogody limitowali do Miłosławia pro octava" (Akta sejmikowe 16961732, s. 575). 
Po 1717 r., kiedy wyraźnie zmniejszyła się liczba zgromadzeń sejmikowych, odbywano je wyłącznie w Środzie, przestrzegając wielowiekowej zwyczajowości miejsca ${ }^{55}$.

Podobnie czynił sejmik za panowania Augusta III. W latach 1733-1763 na 92 sklasyfikowane i realnie zwołane zgromadzenia zaledwie siedem odbyło się poza Środą ${ }^{56}$. W dniu 21 czerwca 1734 r. w Kaliszu, pod laską marszałka konfederacji Jana Andrzeja Palędzkiego, chorążyca bydgoskiego, zjechała się szlachta popierająca elekcję Stanisława Leszczyńskiego. Nadzwyczajność miejsca sejmiku z limity, wyznaczonego w uniwersale marszałkowskim, podyktowana była wówczas okolicznościami politycznymi - toczącą się wojną o tron polski i rozłamem politycznym w łonie wielkopolskiej szlachty. Już 25 sierpnia tegoż roku zaszła potrzeba odbycia nadzwyczajnego zjazdu w Gnieźnie w celu odpowiedzi na działania przeciwników ${ }^{57}$. Po raz kolejny złamano uświęconą tradycję dopiero wobec tragicznych konsekwencji bezceremonialnych działań na terenie Wielkopolski pruskich i rosyjskich oddziałów walczących podczas wojny siedmioletniej. W dniu 26 czerwca 1760 r. szlachta obu województw zjechała się w Poznaniu, aby zareagować na uniwersał w sprawie wydawania prowiantów, wystawiony przez rosyjskiego generała Wasilija Iwanowicza Suworowa ${ }^{58}$. Z podobnych powodów zebrano się w Poznaniu również $\mathrm{w}$ grudniu $1761 \mathrm{r} .{ }^{59}$. Kontrybucje nakładane z kolei przez pruskiego puł-

${ }^{55}$ Szerzej o funkcjonowaniu samorządu sejmikowego województw poznańskiego i kaliskiego zob. M. Zwierzykowski, Samorzad sejmikowy.

${ }^{56}$ Akta sejmikowe województw poznańskiego i kaliskiego. Lata 1733-1763, wyd. M. Zwierzykowski, Warszawa 2015; S. Pomykaj, Sejmiki wielkopolskie w Środzie w latach 1733-1763, Kalisz 1932; G. Glabisz, Województwa poznańskie i kaliskie w bezkrólewiu 1733 roku, w: W podróży przez wiek osiemnasty. Studia i szkice z epoki nowożytnej, red. A. Perłakowski, M. Wyszomirska, M. Zwierzykowski, Kraków 2015, s. 51-69; idem, Konfederacja partykularna województw poznańskiego i kaliskiego przy majestacie Stanisława Leszczyńskiego w latach 1733-1735, „Klio" 2016, 37, 2, s. 61-86; idem, Pacyfikacja województw poznańskiego i kaliskiego w latach 1734-1736 [artykuł złożony do druku].

${ }^{57}$ Uniwersał marszałka sejmiku J.A. Palędzkiego, chorążyca bydgoskiego - obóz pod Nowym Miastem, 5 VI 1734 (Akta sejmikowe 1733-1763, s. 105); zjazd w Gnieźnie został pominięty w edycji akt sejmikowych $\mathrm{z}$ tego okresu, gdyż nie odnaleziono na jego temat materiałów źródłowych, wspomniał jednak o nim L. Hubert (idem, Adam na Melsztynie i Czekarzewicach Tarło, wojewoda lubelski, w: idem, Pamiętniki historyczne, t. 2, Warszawa 1861, s. 180).

${ }^{58}$ Ordynans Wasilija Iwanowicza Suworowa generała porucznika wojsk rosyjskich, komendanta poznańskiego w sprawie prowiantów - Poznań 1 VI 1760 (Akta sejmikowe 1733-1763, s. 613); Punkta spisane podczas zjazdu senatorów i urzędników - Poznań 26 VI 1760 (Akta sejmikowe 1733-1763, s. 617 i nn).

${ }_{59}$ Uniwersał Kaspra Rogalińskiego starosty obornickiego do województw poznańskiego i kaliskiego z informacją o decyzjach zjazdu senatorów i urzędników w Pozna- 
kownika Daniela Friedricha von Lossow i jego huzarów zmusiły wielkopolską szlachtę do trzech kolejnych zjazdów - w Poznaniu $\left(29\right.$ IV $^{60}$ i $28 \mathrm{~V}$ $1763 \mathrm{r}^{61}$ ) i Kaliszu (16 V 1763²). Pojawienie się po bardzo długiej przerwie oddolnie zwoływanych zjazdów polityczny $\mathrm{ch}^{63}$, niemieszczących się $\mathrm{w}$ formalnych ramach zgromadzenia sejmikowego, było skutkiem totalnej zapaści sejmiku województw, którego większość, nielicznych zresztą zgromadzeń, była notorycznie zrywana, co pozostawiało pogrążoną w rozpaczy, grabioną i poniżaną szlachtę bez żadnej pomocy. Nie mogła ona również liczyć na wsparcie ze strony równie bezsilnego władcy oraz jego ministrów, którzy ograniczali się do nieskutecznych działań dyplomatycznych. Zjazdy te, potępiane w korespondencji przez przywódców politycznych jako nieskuteczne, pokazują jednak, że mechanizmy oddolnego nacisku na zmiany w funkcjonowaniu politycznego państwa, które uległy znacznemu osłabieniu po $1717 \mathrm{r}$. i porażce w okresie wojny lat 1734-1735, odżyły ponownie w końcu panowania Augusta III i nie były wyłącznie wynikiem gry stronnictw. Układ sił międzynarodowych i słabość Rzeczypospolitej nie pozwoliły już jednak na ich rozwinięcie. Zostały brutalnie stłumione przez wojska rosyjskie w pierwszych latach panowania Stanisława Augusta i upokorzone podczas konfederacji barskiej.

Za panowania Stanisława Augusta Poniatowskiego, prawie do końca istnienia Rzeczypospolitej, Środa była nadal stolicą sejmikową Wielkopolski. Wyjątek może stanowić jedynie konfederackie zgromadzenie, które odbyło się 27 maja 1767 r. w Krotoszynie ${ }^{64}$ oraz obrady według wspomnianej wcześniej reformy sejmików z 1768 r., odwołanej w 1776 r. (również podczas konfederacji barskiej zjazdy odbywały się $\mathrm{w}$ różnych, dogodnych z politycznego i militarnego punktu widzenia miejscach ${ }^{65}$ ).

niu w sprawie aprowizacji wojsk rosyjskich - Poznań XII 1761 (Akta sejmikowe 1733-1763, s. 722).

${ }^{60}$ List senatorów województw poznańskiego i kaliskiego do prymasa Władysława Łubieńskiego - Poznań 29 IV 1763 (Akta sejmikowe 1733-1763, s. 783).

${ }^{61}$ Instrukcja i dezyderaty województwa poznańskiego spisane dla Józefa Mycielskiego starosty konińskiego, posła do prymasa Władysława Łubieńskiego - Poznań 28 V 1763 (Akta sejmikowe 1733-1763, s. 788).

${ }^{62}$ Instrukcja i dezyderaty województwa kaliskiego spisane dla Ksawerego Sokolnickiego podkomorzego kaliskiego, posła do prymasa Władysława Łubieńskiego - Kalisz 16 V 1763 (Akta sejmikowe 1733-1763, s. 786).

${ }^{63}$ Ostatnie tego typu zjazdy miały miejsce w latach 1703-1704, podczas narastającego konfliktu między Augustem II i opozycją w okresie wielkiej wojny północnej (M. Zwierzykowski, Samorząd sejmikowy, s. 357), a najprawdopodobniej również w 1735 r.

${ }^{64}$ Laudum sejmiku w Krotoszynie 27 V 1767 (AP Poznań, Gr. Poznań 1221, k. 232 $237 \mathrm{v})$.

${ }^{65}$ W. Szczygielski, Konfederacja barska w Wielkopolsce 1768-1770, Warszawa 1970; 
Według ustaleń Witolda Filipczaka w latach 1780-1786 w Wielkopolsce właściwej odbyło się 12 zgromadzeń sejmiku, wszystkie w Środzie. Poza tym zebrało się 9 elekcji na urzędy sądowe ziemskie (4 wschowskie, 3 kaliskie, 1 poznańska i 1 gnieźnieńska) ${ }^{66}$. Decyzje podjęte przez Sejm Wielki zwiastowały już jednak istotne zmiany i odejście od zwyczaju, podyktowane racjonalnym i praktycznym postrzeganiem instytucji sejmiku, dla którego ponownie przewidziano ważne zadania $\mathrm{w}$ aparacie administracyjnym państwa.

Warto w tym miejscu zastanowić się również nad praktyką odbywania się obrad w tradycyjnym, zwyczajowym miejscu wielkopolskiego sejmikowania w Środzie. W najlepiej dotychczas przebadanym okresie funkcjonowania samorządu sejmikowego w Wielkopolsce w latach 1696-1763 przeważająca część obrad odbyła się w zwyczajowym miejscu. Jak już wspominaliśmy, w latach 1696-1732 na 206 ustalonych zgromadzeń aż $178(86 \%)$ miało miejsce w Środzie. W przypadku sejmikowania w latach 1733-1763 sytuacja jeszcze bardziej się ustabilizowała - na 91 rzeczywiście zwołanych zgromadzeń sejmikowych aż 85 (ponad 93\%) odbyło się w Środzie ${ }^{67}$.

„Szukać by istotnie nadaremno w dzisiejszej Środzie jakich bądź śladów minionej, pokaźnej przeszłości politycznej, a jedynym jej pomnikiem piękna i wspaniała, ze ściętą u góry wieża, obwiedziona dookoła murem kolegiata"68. Tymi słowami Kazimierz Jarochowski przywoływał wspomnienie o dawnej świetności stolicy wielkopolskich sejmików. W tonie wypowiedzi pobrzmiewa nostalgia za minionym bezpowrotnie okresem, bowiem za życia autora powyższego cytatu miasto nie pretendowało już do miana centralnego ośrodka politycznego w Wielkopolsce. Nieprzemijającą ozdobą Środy, którą również zachwycał się K. Jarochowski, była i jest nadal kolegiata pod wezwaniem Wniebowzięcia Najświętszej Marii Panny. W praktyce to ona stanowiła ścisłe "centrum" wielkopolskiego samorządu sejmikowego od XV do XVIII w. Jej wnętrze i przyległości, czyli plac i cmentarz, służyły jako miejsce obrad sejmiku województwa poznańskiego i kaliskiego, a praktyka ta uświęcona była wielowiekową tradycją.

Jak wspomniano, zarówno w XIX w., tak i obecnie Środa nie pełni już doniosłej jak w czasach nowożytnych funkcji. W okresie, gdy była niekwestionowaną „,stolicą" sejmików województw wielkopolskich, należała do

Z. Chodyła, Koszty ekonomiczne konfederacji barskiej (1768-1772) w Wielkopolsce, Poznań 1982 [rozprawa doktorska, mps w Bibl. Gł. UAM].

${ }^{66}$ W. Filipczak, Życie sejmikowe, s. 286.

${ }^{67}$ M. Zwierzykowski, Samorzad sejmikowy, s. 28; Akta sejmikowe 1733-1763.

${ }^{68} \mathrm{~K}$. Jarochowski, Lauda połaczonych województw kaliskiego i poznańskiego za panowania Augusta II, w: Zdobywcy i okupanci staropolskiego Poznania, Poznań 2007, s. 145. 
znaczniejszych miast regionu. Pod względem liczby ludności, która od XVI do połowy XVII w. wynosiła około 1700 stałych mieszkańców, Środę można zakwalifikować do miast trzeciej kategorii ${ }^{69}$. Po potopie szwedzkim liczba ta zmniejszyła się znacznie, powróciła zaś do pierwotnej wartości dopiero pod koniec XVIII w.

Ponieważ dokument lokacyjny nie zachował się do naszych czasów, nie znamy dokładnej daty przyznania Środzie praw miejskich. Można jedynie przypuszczać, iż miało to miejsce w drugiej połowie XIII w., a lokacja nastąpiła na podstawie prawa magdeburskiego ${ }^{70}$. Warto dodać, że do końca Rzeczypospolitej szlacheckiej była miastem królewskim pod opieką starosty niegrodowego ${ }^{71}$. Do niego należał zamek, który niestety już pod koniec XVII w. popadł w ruinę, a na początku XVIII w. nie nadawał się zupełnie do rezydowania ${ }^{72}$.

Układ architektoniczny miasta w omawianej epoce był nadal typowo średniowieczny. Centrum stanowił rynek w kształcie kwadratu, na środku którego stał ratusz z wieżą. Z każdego narożnika rynku biegła ulica łącząca poprzeczne uliczki. Miasto otaczały mury i fosa, które nadały mu kształt owalny ${ }^{73}$. Wejścia do niego strzegły cztery bramy: Poznańska, Górecka, Pyzdrska oraz Wszystkich Świętych. Przestrzeń miejska zamknięta wałami była niewielka. Nie dziwi więc, że z czasem za każdą z bram powstały przedmieścia ${ }^{74}$. Centrum miasta otoczone murami obejmowało wspomniany już zamek i ratusz, a także budynek szkoły, spichrze, domki senatorów oraz kolegiatę. Widać zatem, iż niewiele budynków mogło być branych ówcześnie pod uwage przy wyborze gmachu na zjazdy szlacheckie. Zresztą przykład sejmiku średzkiego, odbywającego się na terenie kościelnym, nie jest odosobniony w Koronie w okresie staropolskim i wskazuje raczej na fakt, iż w mniejszych miejscowościach, które nie posiadały okazałych zamków czy ratuszy, kościoły stanowiły wygodną alternatywę dla pomieszczenia większych zgromadzeń publicznych ${ }^{75}$. Ponadto warto mieć na uwadze to, że zamki były siedzibami funkcjonariuszy państwowych lub osób prywatnych, które mogłyby wywierać wpływ na sejmikującą szlachtę, czego ta ostatnia wolała uniknąć. Przyczyną dość oczywi-

${ }^{69}$ Dzieje Środy Wielkopolskiej i jej regionu, t. 1, red. S. Nawrocki, Środa Wielkopolska 1990, s. 61.

${ }^{70}$ Ibidem, s. 35.

${ }^{71}$ L. Gomolec, Ziemia średzka, Środa 1935, s. 41.

${ }^{72}$ Dzieje Środy, s. 71.

${ }^{73}$ Ibidem, s. 69.

${ }^{74}$ L. Gomolec, op. cit., s. 50.

${ }^{75}$ W. Maisel, op. cit., s. 65-66. 
stą była także perspektywa zniszczeń, jakie poczynić mogło zgromadzenie sejmikujących na miejscu obrad, co stanowiłoby dyskomfort dla właściciela zamku.

Goszczenie szlachty podczas sejmików, z jednej strony, podnosiło rangę miasta, z drugiej - przysparzało mu kłopotów. W niewielkim centrum miasta znajdowało się tylko kilka budynków mogących służyć jako zakwaterowanie dla przybyłej na sejmik szlachty. Problem ten starali się rozwiązać sami zainteresowani. Dla przykładu, w laudum z 23 października 1696 r. sejmik nakazał mieszczańskim i szlacheckim posiadaczom pustych placów na terenie miasta ich natychmiastową zabudowę ${ }^{76}$. O tym, że sytuacja z bazą noclegową była trudna, świadczy wyrażona $\mathrm{w}$ dokumencie motywacja podejmujących uchwałę: „,[...] chcąc mieć lepsze wygody na sejmikach średzkich, które teraz bardzo złe dla szczupłości gospód i popustoszałych placów"77. Inną próbą poradzenia sobie z tym problemem była praktyka udzielania bezzwrotnych pożyczek mieszkańcom Środy na wyremontowanie lub odbudowanie domu. Jedynym warunkiem takiej pożyczki było zobowiązanie się przez dłużnika do udzielania dożywotniej gościny, czasem nawet rozciąganej na spadkobierców ${ }^{78}$.

Sytuacja Środy uległa drastycznemu pogorszeniu po pożarze, jaki miał miejsce 16 maja 1697 r. Tego dnia spłonęła znaczna część miasta. Dlatego też szlachta, która przybyła do Środy w marcu następnego roku na sejmik przedsejmowy, nie znalazłszy noclegu, musiała rozlokować się po okolicznych wsiach ${ }^{79}$. W celu wspomożenia mieszkańców w odbudowie miasta szlachta uchwałą sejmiku zwolniła ich z podatków ${ }^{80}$.

Kolegiata średzka, o której już wspominano, została wzniesiona w stylu gotyckim na początku XV w. Nie wiemy jednak, kto i kiedy dokładnie podjął decyzję o budowie kościoła parafialnego w Środzie ${ }^{81}$. Przywilej erekcyjny dla kolegiaty wystawił w 1423 r., w imieniu biskupa Łaskarza Gosławskiego wikariusz generalny i kanonik poznański Mikołaj Kicki. Przypuszczać można, iż erygowana na początku XV w. murowana świątynia zastąpiła wzniesiony wcześniej drewniany kościół oraz przejęła jego wezwanie ${ }^{82}$.

Budynek kolegiaty, początkowo jednonawowy, tradycyjnie dla średniowiecznych kościołów skierowany został prezbiterium na wschód.

\footnotetext{
${ }^{76}$ Akta sejmikowe 1696-1732, s. 58.

${ }_{77}$ Ibidem.

${ }^{78}$ M. Zwierzykowski, Sejmik województw, s. 410.

${ }^{79}$ Akta sejmikowe 1696-1732, s. 138.

${ }^{80}$ M. Zwierzykowski, Sejmik województw, s. 410.

${ }^{81}$ J. Łukaszewicz, Krótki opis kościotów parochialnych, t. 1, Poznań 1958, s. 315.

${ }^{82}$ B. Urbańska, op. cit., s. 20.
} 
W wyniku kolejnych przeróbek i remontów bryła świątyni uległa sporym przeobrażeniom. Już na przełomie XV i XVI w. okazało się, iż jedna nawa nie wystarcza na pomieszczenie coraz liczniejszych wiernych i zgromadzeń sejmikowych. Przypomnijmy tylko, że już od pierwszej połowy XV w. Środa była sceną wielu politycznych debat szlachty obu wielkopolskich województw. Kościół rozbudowano o nawy boczne: północną i południową oraz o monumentalną wieżęe ${ }^{83}$ Warto nadmienić jednak, iż pierwszą przeróbkę kościoła stanowiła fundacja kaplicy konfraterni kapłanów, identyczna topograficznie z późniejszą kaplicą Pampowskich pod wezwaniem Marii Magdaleny, nazywaną także kaplicą Grzymułtowskich ${ }^{84}$. Niestety, nie zachowała się ona do naszych czasów. W 1869 r. w wyniku przebudowy została otwarta na nawę południową i włączona w jej obręb $b^{85}$.

Trzecią i ostatnią z kaplic, jakie ufundowano dla kolegiaty średzkiej, była kaplica Gostomskich, którą dobudował na przełomie XVI i XVII w. wojewoda poznański Hieronim Gostomski na podstawie przywileju króla Zygmunta III. Patronat nad nią mieli sprawować poznańscy jezuici ${ }^{86}$. Kaplica została wzniesiona na planie ośmioboku i zwieńczona oszkloną latarnią. Do najcenniejszych elementów jej wystroju należy późnorenesansowa spiżowa krata oddzielająca kaplicę od prezbiterium oraz wczesnobarokowy nagrobek małżonki fundatora Urszuli Sieniawskiej. Renesansowa forma i wystrój kaplicy do dziś wyróżniają się zarówno na tle wewnętrznych, jak i zewnętrznych dekoracji architektonicznych gotyckiego przecież kościoła ${ }^{87}$.

Zatrzymajmy się na chwilę przy wykonanych z brązu wrotach zamykających fundację Gostomskich od strony prezbiterium. Omawiana kaplica bywała bowiem najprawdopodobniej miejscem urzędowania sekretarza sejmikowego, który za solidnymi kratami zamkniętymi na klucz mógł czuć się bezpieczny i bezstronny w trakcie szczególnie burzliwych obrad odbywanych w kościele ${ }^{88}$. Taka sytuacja nie była jednak częsta, w związku z faktem, że najczęściej obradowano jednak na przylegającym do kolegiaty cmentarzu.

${ }^{83}$ J. Nowacki, Dzieje Archidiecezji Poznańskiej, t. 2, Poznań 1964, s. 605.

${ }^{84}$ B. Urbańska, op. cit., s. 22.

${ }^{85}$ Kosztem kaplicy zamierzano powiększyć północną nawę kościoła. Ponadto, jak argumentowali pomysłodawcy rozbiórki, kaplica była w złym stanie technicznym - w ścianę zewnętrzną wdała się wilgoć, która mogłaby doprowadzić do zawalenia; zob. B. Urbańska, op. cit., s. 41.

${ }^{86}$ L. Gomolec, op. cit., s. 45.

${ }^{87}$ Ibidem.

${ }^{88} \mathrm{~K}$. Jarochowski, op. cit., s. 146. 
Trudno dziś ustalić z całą pewnościa, jakie było pierwotne wyposażenie kościoła, czyli jaka była sceneria, na tle której toczyły się obrady sejmików ${ }^{89}$. Wiemy na pewno, że dzisiejszy dwukondygnacyjny ołtarz główny jest międzywojenną rekonstrukcją ołtarza według wzorca z XVII w. Zastąpił on wcześniejszy „fabrykat niemiecki” z Monachium, który umieszczono $\mathrm{w}$ prezbiterium pod koniec XIX w. ${ }^{90}$. Co do wcześniejszego wyglądu prezbiterium, dane odnalezione w źródłach nie są jednoznaczne. Prawdopodobnie pierwszy ołtarz, ufundowany zaraz po erygowaniu kolegiaty, został zastąpiony w połowie XVI w. kolejnym, tym razem renesansowym. Jednakże co do fundatora brak jednoznacznej odpowiedzi. Obok ołtarza głównego w kościele znajdowało się także 12 ołtarzy bocznych przeznaczonych na kult świętych ${ }^{91}$.

W tym miejscu warto wspomnieć też o zakrystii. Brak pewności, czy miejsce to dawniej pełniło również funkcję „zaplecza” kościelnego. Wiemy, że na początku przybudówka, będąca dziś zakrystia, składała się z dwóch kondygnacji. Niższa część mogła pierwotnie łączyć tę funkcję z kaplica, co do wyższej zaś w literaturze przedmiotu są domniemania, że przeznaczano ją na potrzeby sejmikujących jako skarbczyk na dokumenty sejmikowe ${ }^{92}$. Jednakże hipotezę tę należy zdecydowanie odrzucić, bowiem sejmiki nie przechowywały na miejscu żadnej dokumentacji, ponieważ nie posiadały stacjonarnego archiwum ${ }^{93}$. Jeśli chodzi natomiast o probostwo, znajdowało się ono w pobliżu kolegiaty, za cmentarnym murem. Dopiero pod koniec XVII w., jak dowiadujemy się z akt wizytacji parafii średzkiej w 1695 r., zalecono jego gruntowny remont ${ }^{94}$. Upływający czas i kolejne zniszczenia powstałe podczas wojny północnej doprowadziły do całkowitej ruiny budynku, a w dalszej konsekwencji do podjęcia decyzji o rozbiórce probostwa, o czym donosi następny z wizytujących w $1727 \mathrm{r}$. kolegiatę, kanonik poznański Franciszek Libowicz ${ }^{95}$.

Do najstarszych dekoracji kolegiaty można zaliczyć dwie płaskorzeźby z piaskowca. Pierwsza z nich przedstawia Ducha Świętego pod postacią gołębicy i datowana jest na początek XVI w. Kolejna zaś to pochodzący z XVII w. wizerunek Boga Ojca, który jedną ręką podtrzymuje świat, a drugą unosi w geście błogosławieństwa. Ciekawe były przy-

\footnotetext{
${ }^{89}$ B. Urbańska, op. cit., s. 26.

${ }^{90}$ L. Gomolec, op. cit., s. 47.

${ }^{91}$ AA Poznań, Akta wizytacji - AV 18, k. 290v.

${ }^{92}$ B. Urbańska, op. cit., s. 22.

${ }^{93}$ M. Zwierzykowski, Samorząd sejmikowy, s. 28.

${ }^{94}$ AA Poznań, Akta wizytacji - AV 18, k. 313v.

${ }^{95}$ AA Poznań, Akta wizytacji - AV 20, k. 533v.
} 
puszczenia Ludwika Gomolca, średzkiego regionalisty, co do funkcji pełnionych przez obie płaskorzeźby. Domniemywał on bowiem, że mogły stanowić podarunek sejmikującej szlachty $\mathrm{w}$ ramach zadośćuczynienia za niewłaściwe zachowanie w kościele podczas obrad. Jako datę przekazania daru wyznaczył rok 1646. Przypuszczenie to skłania do namysłu, gdyż w rzeczywistości zebrana na sejmikach szlachta niejednokrotnie sięgała po broń i dochodziła swych racji na drodze niekoniecznie dyplomatycznej. Najbardziej znana i szeroko komentowana w Rzeczypospolitej była oczywiście sprawa ciężkiego poranienia podczas sejmiku relacyjnego 20 maja 1670 r. w średzkiej kolegiacie kasztelana poznańskiego Krzysztofa Grzymułtowskiego ${ }^{96}$. Podarowane rzeźby mogły więc stanowić fragmenty zastępczego sakramentarium, w którym deponowano Najświętszy Sakrament na czas burzliwych obrad. Jako kolejny argument L. Gomolec podaje fakt, iż bliźniacze płaskorzeźby znajdują się w kościele w Kole, będącym miejscem zjazdów prowincjonalnych. Jednakże powyższa hipoteza nie znajduje potwierdzenia zarówno w źródłach, jak i w literaturze przedmiotu.

Spośród przedmiotów stanowiących wystrój kolegiaty na uwagę zasługują również cztery drewniane stalle z 23 miejscami do siedzenia, umieszczone $\mathrm{w}$ prezbiterium, $\mathrm{z}$ których aż trzy posiadają malowane zaplecki z przedstawieniami świętych. Najstarsze z nich pochodzą z pierwszej połowy XVI w., pozostałe z połowy tego stulecia ${ }^{97}$. Przeznaczone były dla duchowieństwa gromadzącego się wspólnie przynajmniej raz dziennie dla odśpiewania nabożeństwa, a w trakcie sejmiku zajmowali je z pewnością znaczniejsi przedstawiciele wielkopolskiej szlachty. W kościele znajdowało się jeszcze jedno stallum - w kaplicy Gostomskich, a także ławy w liczbie ponad 40, o czym donoszą akta wizytacji z końca XVII w. Część siedzisk była nowa, część natomiast Mikołaj Zalaszowski, archidiakon przeprowadzający wizytację kolegiaty, określił jako bardzo stare (,,scamna vero antiqua” $)^{98}$.

Z wyżej wspomnianych akt wizytacji z lat 1696 i 1727 wynika również, iż na przełomie XVII i XVIII w. kościół był zadbany: mury, zadaszenie oraz witraże nie wymagały remontów. Podłoga wykonana była z drewna dębowego. Na wyposażeniu kościoła znajdował się, obok wyżej wymienionych sprzętów, jeden konfesjonał, trzy dzwony oraz odpo-

96 A. Kamieński, Problem ochrony zgromadzeń ziemskich w Polsce XVI-XVIII w. (na przykładzie sejmiku województw poznańskiego i kaliskiego w Środzie), w: Sejmiki wielkopolskie. Przeszłość i teraźniejszość, red. A. Kamieński, Szczecin-Jarocin 2008, s. 39.

${ }^{97}$ B. Urbańska, op. cit., s. 187-190.

${ }^{98}$ AA Poznań, Akta wizytacji - AV 18, k. 290. 
wiednio ozdobiony chór z wyremontowanymi organami o dwudziestu tonach. Niezadowolenie budził jedynie stan plebanii, na którą uskarżał się w 1727 r. wspominany już kanonik poznański Franciszek Libowicz ${ }^{99}$.

Nie można pominąć jeszcze jednego elementu wystroju kolegiaty, a mianowicie belki tęczowej z krucyfiksem i wielofigurową grupą pasyjna, umieszczoną nad przejściem z prezbiterium do nawy głównej, a datowaną na początek XVI w. Zwieńczona ostrołukiem sklepienia, którego kształt przypominał gest złożonych dłoni, miała kierować myśli zebranych ku skupieniu i modlitwie ${ }^{100}$. Pośród akt sejmikowych zachowała się relacja z rozdwojonego sejmiku przedsejmowego w Środzie z 5 marca 1698 r., z której dowiadujemy się nie tylko o dramatycznym przebiegu zjazdu, lecz również o znaczeniu symbolu, jakim była dla zgromadzonej szlachty belka tęczowa z krzyżem. Kiedy kasztelan poznański Melchior Gurowski rozpoczął czytanie uniwersału królewskiego, rokoszanie (zwolennicy elekcji księcia Contiego) przerwali mu, „wypadli z ławek i rzucili się do szabel, nie chcąc z kościoła wypuścić ichm. i pryncypała ${ }^{101}$ życząc sobie dosiąc" ${ }^{\prime 102}$. Dalej czytamy, że zaatakowana szlachta, skupiona przede wszystkim w małym chórze, próbowała przebić się przez tłum rokoszan w stronę wyjścia. Krzyczała, prosząc przy tym i wskazując „na Krucyfiks w pół kościoła będący, aby pamiętając na Boga, krwi między sobą wylania nie pragnęli" 103 .

Jak zauważono, obrady sejmików szlacheckich w Środzie miały miejsce nie tylko w samej kolegiacie, gdzie odbywało się zazwyczaj nabożeństwo poprzedzające zjazd, a także zagajenie sejmiku i czytanie uniwersału królewskiego, lecz częściej nawet na terenie jej przyległości: placu przykościelnym oraz cmentarzu. Jednakże wybór jednego z tych miejsc sprawiał nierzadko problem sejmikującym i prowokował kłótnie. Argumentem za obradowaniem na cmentarzu była często większa frekwencja przybyłej na sejmik szlachty i długotrwały zwyczaj. Do dyskusji na temat obrania miejsca obrad doszło m.in. podczas sejmiku deputackiego i relacyjnego, który odbył się 10 września 1590 r. Po wyborze marszałka część szlachty poprosiła o przeniesienie sejmiku na cmentarz, jak argumentowała „dla więtszego koła”"104. Pozostali odpowiedzieli, iż „nieraz się ten akt w kościele odprawował i teraz, by też i trzykroć więtsza liczba braci była, miej-

\footnotetext{
${ }^{99} \mathrm{~W}$ aktach wizytacji z 12 III 1727 czytamy: „Quae residentia sub tempus hostilitatis totaliter diruta et sublata est" (AAP, Akta wizytacji - AV 20, Środa, k. 533).

${ }^{100}$ B. Urbańska, op. cit., s. 205.

${ }^{101}$ Chodzi o kasztelana poznańskiego Melchiora Gurowskiego.

102 Akta sejmikowe 1696-1732, s. 138.

${ }^{103}$ Akta sejmikowe 1696-1732, s. 139.

${ }^{104}$ Akta sejmikowe 1572-1616, s. 138.
} 
sca by dosyć w kościele mieli"105. Ostatecznie przychylono się do prośby i zgromadzenie przeniosło obrady na cmentarz. Kontrargumentem, który ewentualnie byłby $\mathrm{w}$ stanie przechylić szalę i spowodować pozostanie wszystkich w kolegiacie, mógł być deszcz, śnieg bądź dotkliwe zimno, które utrudniałyby przebieg posiedzenia ${ }^{106}$.

Na kartach akt sejmikowych znajdziemy również relację informującą o jeszcze innej praktyce sejmikujących związanej z cmentarzem. Podczas sejmiku, który odbył się przed sejmem koronacyjnym w Środzie 6 sierpnia 1697 r., przeciwnicy elekcji Fryderyka Augusta Wettyna za wszelką cenę próbowali nie dopuścić do zagajenia sejmiku. Gdy stronnicy Sasa nie chcieli się rozejść, „opozycjoniści” zagrozili, że sami też nie odejdą i każą przynieść sobie pościel na cmentarz, gdzie byli zgromadzeni ${ }^{107}$.

Warto w tym miejscu dodać jeszcze kilka słów na temat cmentarza. Zajmował on wówczas północną oraz południowo-wschodnią stronę terenu przykościelnego. Ogrodzony był nie tylko od strony zewnętrznej, lecz także od strony placu przed kościołem. $Z$ dokumentacji powstałej podczas przeprowadzania remontów kolegiaty wynika, iż w połowie XIX w. zarówno mur, jak i ogrodzenie były kompletnie zrujnowane ${ }^{108}$. Ostatnie pochówki miały tam miejsce jeszcze na początku XIX w. (pomimo oficjalnego zakazu władz kościelnych).

Jako miejsce nadające się do odbywania posiedzeń sejmikowych uznawany był również plac przed kościołem. Z publikacji poświęconych historii Środy wiadomo, że po zagajeniu sejmiku senatorowie kontynuowali obrady w kolegiacie, pozostała zaś szlachta zasiadała w ławach wystawionych na cmentarzu lub przed kościołem ${ }^{109}$. Obraz obradującego na placu koła rycerskiego utrwalony został w świadomości potomnych także za sprawą XIX-wiecznego miedziorytu L. Passiniego. Otóż praktyka podziału sejmikujących na dwa koła miała miejsce jedynie we wczesnym okresie funkcjonowania tej instytucji. W okresie staropolskim koło rycerskie oraz senatorowie obradowali razem.

O tym, że ławy sejmikowe rzeczywiście znajdowały się w posiadaniu parafii, świadczy informacja $z$ archiwum parafialnego o ich sprzedaży za ponad 16 talarów w 1798 r. ${ }^{110}$. Były to jednakże ławy późniejsze, zamówione przez sejmik dopiero w 1764 r. O dyspozycji zakupu informuje lau-

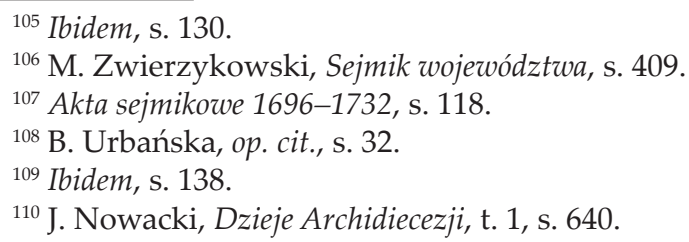


dum sejmiku gospodarskiego z 6 listopada 1764 r. ${ }^{111}$. Najprawdopodobniej te właśnie ławy zostały utrwalone przez L. Passiniego na wspomnianym już miedziorycie. Co więcej, obowiązek zakupu ław został potwierdzony w czasie sejmu koronacyjnego w konstytucji z 3 grudnia 1764 r. ${ }^{112}$. Jednakże o tym, czy przed ich zakupem szlachta korzystała z innych siedzisk przygotowanych specjalnie na użytek sejmikujących, w źródłach nie ma informacji. Korzystano zapewne z ław kościelnych, które na czas sejmiku wynoszono z kolegiaty. Jedno jest pewne - miejsc siedzących nie było zbyt wiele. Aby temu zaradzić szlachta przywoziła ze sobą prywatne stołki („krzesełka sejmikowe”), o istnieniu których wiemy m.in. dzięki kwerendzie przeprowadzonej przez Jarosława Dumanowskiego w inwentarzach szlachty wielkopolskiej ${ }^{113}$.

Dzięki prowadzonym przez ponad dwa wieki pracom remontowym w kolegiacie i na terenie przykościelnym miejsca te nadal zachwycają zwiedzających. Jednakże o dawnej bytności w tym miejscu sejmikujących świadczy na pierwszy rzut oka niewiele. Nie ma już amfiteatralnie rozstawionych ław, a skora do kłótni i huczków szlachta, pomimo temperamentu, nie pozostawiła żadnych śladów na murach kościoła. Dopiero po analizie historii zgromadzonych wewnątrz przedmiotów oraz źródeł pisanych, co starano się w niniejszym opracowaniu uczynić, dostrzec można, jak wiele łączy je z sejmikową przeszłością.

\section{BIBLIOGRAFIA}

\section{Źródła rękopiśmienne}

Archiwum Archidiecezjalne w Poznaniu:

Akta wizytacji - AV 18, 20.

Archiwum Państwowe w Poznaniu:

Księgi grodzkie gnieźnieńskie - 209, 211, 212, 245, 260.

Księgi grodzkie kcyńskie - 164.

Księgi grodzkie poznańskie - 1221.

\section{Źródła drukowane}

Akta sejmikowe województw poznańskiego i kaliskiego, t. 1: 1572-1632, wyd. W. Dworzaczek, cz. 1: 1572-1616, Poznań 1957, cz. 2: 1616-1632, Poznań 1961.

Akta sejmikowe województw poznańskiego i kaliskiego. Lata 1696-1732, wyd. M. Zwierzykowski, Poznań 2008.

${ }^{111}$ M. Zwierzykowski, Samorząd sejmikowy, s. 31.

112 „Dla porządnego zaś wotowania też Województwa ławki na cmentarzu srzedzkim zrobić dla każdego powiatu każą, aby nikt z innego miejsca, tylko z swej powiatowej ławki wotował, sub non acceptatione voti [...]", zob. VL, t. 7, s. 155.

${ }^{113}$ M. Zwierzykowski, Samorzad sejmikowy, s. 32 - tam informacje o krzesełkach odnalezionych przez J. Dumanowskiego. 
Akta sejmikowe województw poznańskiego i kaliskiego. Lata 1733-1763, wyd. M. Zwierzykowski, Warszawa 2015.

Volumina constitutionum, t. 1, vol. 1: 1493-1526, Warszawa 1996.

Volumina legum, t. 7-8, wyd. J. Ohryzko, Petersburg 1860.

Volumina legum, t. 9, wyd. zespół, Kraków 1889.

\section{Literatura}

Bardach J., Leśnodorski B., Pietrzak M., Historia ustroju i prawa polskiego, Warszawa 1994.

Bednaruk W., Trybunat Koronny. Szlachecki sąd najwyższy w latach 1578-1794, Lublin 2008.

Chodyła Z., Koszty ekonomiczne konfederacji barskiej (1768-1772) w Wielkopolsce, Poznań 1982 [rozprawa doktorska, mps w Bibl. Gł. UAM].

Chodyła Z., Utworzenie i początki funkcjonowania województwa gnieźnieńskiego (1768-17741776), w: Gniezno. Studia i materiaty historyczne, t. 2, red. Z. Boras, Warszawa 1987.

Dzieje Jarocina, red. Cz. Łuczak, Poznań 1998.

Dzieje Środy Wielkopolskiej i jej regionu, t. 1, red. S. Nawrocki, Środa Wielkopolska 1990.

Dzieje Wielkopolski, t. 1: Do roku 1793, red. J. Topolski, Poznań 1969.

Filipczak W., Sejmy Rzeczypospolitej w dobie stanisławowskiej, w: Między konstytucja nihil novi a ustawodawstwem nowoczesnej demokracji. Parlamentaryzm polski w XVI-XX w., red. H. Gmiterek, S. Piątkowski, J. Wrona, Radom 2005.

Filipczak W., Życie sejmikowe prowincji wielkopolskiej w latach 1780-1786, Łódź 2012.

Gierowski J.A., Sejmik generalny księstwa mazowieckiego na tle ustroju sejmikowego Mazowsza, Wrocław 1948.

Glabisz G., Konfederacja partykularna województw poznańskiego i kaliskiego przy majestacie Stanisława Leszczyńskiego w latach 1733-1735, „Klio” 2016, 37, 237.

Glabisz G., Pacyfikacja województw poznańskiego i kaliskiego w latach 1734-1736 [artykuł złożony do druku].

Glabisz G., Województwa poznańskie i kaliskie w bezkrólewiu 1733 roku, w: W podróży przez wiek osiemnasty. Studia i szkice z epoki nowożytnej, red. A. Perłakowski, M. Wyszomirska, M. Zwierzykowski, Kraków 2015.

Gomolec L., Ziemia średzka, Środa 1935.

Hubert L., Adam na Melsztynie i Czekarzewicach Tarło, wojewoda lubelski, w: L. Hubert, Pamiętniki historyczne, t. 2, Warszawa 1861.

Jarochowski K., Lauda połaczonych województw kaliskiego i poznańskiego za panowania Augusta II, w: K. Jarochowski, Zdobywcy i okupanci staropolskiego Poznania, Poznań 2007.

Kamieński A., Problem ochrony zgromadzeń ziemskich w Polsce XVI-XVIII w. (na przykładzie sejmiku województw poznańskiego i kaliskiego w Środzie), w: Sejmiki wielkopolskie. Przeszłość i teraźniejszość, red. A. Kamieński, Szczecin-Jarocin 2008.

Kościan. Zarys dziejów, red. Z. Wielgosz, K. Zimniewicz, Warszawa-Poznań 1985.

Lityński A., Z problematyki klasyfikacji sejmików ziemskich, „Prace Naukowe Uniwersytetu Śląskiego" 1969, 5, Prace Prawnicze I.

Łaszewski R., Sejmiki przedsejmowe w Polsce stanisławowskiej. Problemy organizacji i porzadku obrad, „Acta Universitatis Nicolai Copernici” 1977, Prawo XV.

Łukaszewicz J., Krótki opis kościołów parochialnych, t. 1, Poznań 1958.

Maisel W., Archeologia prawna Polski, Warszawa-Poznań 1982.

Nowacki J., Dzieje Archidiecezji Poznańskiej, t. 2, Poznań 1964.

Płaza S., Sejmiki i zjazdy szlacheckie województw poznańskiego i kaliskiego. Ustrój i funkcjonowanie (1572-1632), Kraków 1984.

Pomykaj S., Sejmiki wielkopolskie w Środzie w latach 1733-1763, Kalisz 1932. 
Stronczyński W., Sejmiki wielkopolskie w pierwszej połowie XV w., Poznań 1966 [rozprawa doktorska, mps w Bibl. Gł. UAM].

Szczygielski W., Konfederacja barska w Wielkopolsce 1768-1770, Warszawa 1970.

Topolski J., Pruskie uzurpacje graniczne w dobie pierwszego rozbioru Polski, „Zeszyty Naukowe Uniwersytetu im. Adama Mickiewicza" 1968, Historia, z. 8.

Urbańska B., Kolegiata w Środzie Wielkopolskiej, Środa 2008.

Uruszczak W., Historia państwa i prawa polskiego, t. 1: 966-1795, Warszawa 2013.

Zwierzykowski M., Funkcjonowanie samorzadu sejmikowego województw poznańskiego $i$ kaliskiego od XVI do XVIII w., w: Sejmiki Wielkopolski. Przeszłość i teraźniejszość, red. A. Kamieński, Szczecin-Jarocin 2008.

Zwierzykowski M., Klasyfikacja sejmików na przykładzie funkcjonowania sejmiku województw poznańskiego i kaliskiego w latach 1696-1732, w: O prawie i jego dziejach księgi dwie, ks. 1, red. Zespół, Białystok-Katowice 2010.

Zwierzykowski M., Komisja Skarbowa Poznańska. Z dziejów sejmikowej administracji i sadownictwa skarbowego w Wielkopolsce w XVII i XVIII wieku, Poznań 2003.

Zwierzykowski M., Odrębności ustrojowe Wielkopolski w dobie nowożytnej, w: Między barokiem a oświeceniem. Staropolski regionalizm, red. S. Achremczyk, Olsztyn 2008 [druk 2009].

Zwierzykowski M., Samorzad sejmikowy województw poznańskiego i kaliskiego w latach 16961732, Poznań 2010.

Zwierzykowski M., Sejmik województw poznańskiego i kaliskiego w latach 1696-1702, w: Scripta Minora, t. 4, red. B. Lapis, Poznań 2006.

\section{ABSTRACT}

The article is the first attempt in historiography to synthesise the issue of location of the local parliaments' assemblies in Great Poland in the early modern era, taking into account its genesis and transformation. It is based on existing, not numerous and scattered findings in the literature, and, above all, on the basis of the analysis of extensive, issued already in print, source material for local parliaments of the Poznań and Kalisz Voivodeships. The authors tried to show not only the basics of customary and legal location of the assemblies, the places where over three centuries debated the nobility of Great Poland, but also provide some of the details related to the usual place of those assemblies in Środa. The basic conclusion from the findings in this text confirms that from the second half of the $15^{\text {th }}$ century, Środa was just almost continuously the center of political meetings of the nobility of the vast territory covering two and, since 1768, three voivodeships. Besides, it has been proven that the local parliament of Great Poland in the early modern era did not have a permanent location, but only confirmed by custom and written law the place for assemblies.

Key words: local parliaments, parliamentarism, territorial self-government, Republic of Nobles, history of Great Poland 


\section{NOTA O AUTORACH}

Michał Zwierzykowski - dr hab., prof. UAM, historyk. Jego zainteresowania badacze koncentrują się na historii Polski XVII i XVIII w., ze szczególnym uwzględnieniem dziejów politycznych, ustroju, parlamentaryzmu, samorządów sejmikowych i Wielkopolski oraz biografistyki nowożytnej. Jest autorem licznych monografii i artykułów naukowych, jak również wydawcą źródeł. Prof. M. Zwierzykowski bierze czynny udział w działalności licznych towarzystw i organizacji naukowych, takich jak: Polskie Towarzystwo Historyczne czy Polskie Towarzystwo Badań nad Wiekiem Osiemnastym, jest również członkiem Rady Naukowej i Komitetu Redakcyjnego Polskiego Stownika Biograficznego.

Ewa Tacka - mgr, absolwentka historii na Wydziale Historycznym UAM w Poznaniu. Obecnie uczestnik seminarium doktoranckiego prof. Michała Zwierzykowskiego w Instytucie Historii UAM, prowadzi badania nad funkcjonowaniem elity politycznej województw poznańskiego i kaliskiego w dobie panowania Augusta II. 